\title{
CST2 wt Allele
}

National Cancer Institute

\section{Source}

National Cancer Institute. CST2 wt Allele. NCI Thesaurus. Code C159789.

Human CST 2 wild-type allele is located in the vicinity of 20p11.21 and is approximately 3 $\mathrm{kb}$ in length. This allele, which encodes cystatin-SA protein, plays a role in the regulation of salivary cysteine proteinase activity. 